\title{
Pengaruh Produk, Pelayanan dan Promosi terhadap Keputusan Nasabah untuk Menabung di Bank Syariah ${ }^{1}$
}

\author{
Rijlan Hasanuddin, Ahmad Syukri SS \& Nofrianto \\ Pascasarjana UIN Sulthan Thaha Saifuddin Jambi \\ E-mail: rijlan_pasca@gmail.com
}

\begin{abstract}
This study aims to determine the effect of products, services, and promotions on customer decisions to save at syari'ah banks. This research is a descriptive quantitative research with multiple linear regression analysis method which is conducted at Bank Muamalat Indonesia, Jambi City using the form of field studies (Field Study). The instrument in this study is a questionnaire. The results of this study indicate that the customer's decision to save has a significant effect on products, services and promotions simultaneously. Then about how the product, service and promotion simultaneously influence the customer's decision to save at BMI. That the factors that influence customer interest in saving include customer knowledge about the products in the Muamalat bank itself and the price and place promotions. Not only that, the marketing performance of the marketing work mechanism in promoting product funding to customers by studying customer profiles before creating an account at BMI. Besides, service to customers is very supportive for promotion in influencing customer decisions to save.
\end{abstract}

Keywords: Decision of saving customers, Products, Services, and Promotions.

\begin{abstract}
Abstrak: Penelitian ini bertujuan untuk mengetahui pengaruh produk, pelayanan, dan promosi terhadap keputusan nasabah untuk menabung di bank syari'ah. Penelitian ini adalah penelitian kuantitatif deskriptif dengan metode analisis regresi linear berganda yang dilaksanakan di Bank Muamalat Indonesia Kota Jambi menggunakan bentuk studi lapangan (Field Study). Intrumen dalam penelitian ini adalah kuisioner. Hasil penelitian ini yaitu keputusan nasabah untuk menabung memiliki pengaruh signifikan terhadap produk, pelayanan dan promosi secara simultan. kemudian mengenai bagaimana pengaruh produk, pelayanan dan promosi secara simultan terhadap keputusan nasabah untuk menabung di BMI. Bahwa faktor yang mempengaruhi minat nasabah untuk menabung diantaranya pengetahuan nasabah mengenai produk yang ada di bank muamalat itu sendiri dan dengan harga dan place promotion. Tidak hanya itu kinerja marketing atas mekanisme kerja marketing dalam mempromosikan produk funding kepada nasabah dengan mempelajari profil nasabah sebelum membuat rekening di BMI. Disamping itu pelayanan kepada nasabah sangat mendukung untuk promosi dalam mempengaruhi keputusan nasabah untuk menabung.
\end{abstract}

Kata-kata kunci: Keputusan nasabah menabung, Produk, Pelayanan, dan Promosi.

1 Tulisan ini adalah bagian dari tesis penulis pada Program Pascasarjana UIN Sulthan Thaha Saifuddin Jambi dengan judul yang sama, yang dibimbing oleh Prof. Dr. Ahmad Syukri SS, M.Ag dan Dr. Nofrianto, M.Ag, dan telah diujikan pada April 2019. 


\section{Pendahuluan}

Perkembangan keuangan Islam selama berapa dekade terakhir menunjukkan perubahan serta dinamika secara dramatis dan cepat. Sebagai bagian dari instrument dalam mengembangkan aktivitas di bidang ekonomi, beragam tantangan dihadapi oleh sistem keuangan Islam, seperti tantangan dalam aspek teoritis, operasional dan implementasi. ${ }^{2}$ Pada aspek teoritis, dibutuhkan pengembangan prinsip, filosofis dan fungsi sistem keuangan atas dasar pembagian keuntungan dan kerugian (profit-loss sharing). Pada sisi operasional, dibutuhkan perhatian terhadap inovasi, intermediasi, disiplin dan pengendalian resiko, sementara pada sisi implementasi diperlukan aplikasi sistem yang harus disesuaikan dengan regulasi dan kondisi perekonomian masyarakat saat ini.

Keuangan Islam yang mulai menunjukkan eksistensinya adalah bank yang menawarkan prinsip syariah (bank syariah). Bank syariah merupakan lembaga keuangan yang menghilangkan sistem riba. Peranan perbankan syariah dalam aktivitasnya tidak jauh berbeda dengan perbankan konvensional. Perbedaan antara keduanya terletak pada prinsip-prinsip dalam transaksi keuangan. Salah satu prinsip dalam perbankan syariah adalah penerapan bagi hasil yang sesuai dengan kaidah ajaran Islam. Prinsip ini tidak berlaku di perbankan konvensional yang menerapkan sistem bunga.

Keputusan terkait pemilihan sistem dan penggunaan produk perbankan oleh nasabah merupakan tujuan awal dari bank dalam memasarkan produkproduknya, namun diharapkan apabila nasabah menaruh sikap positif dalam evaluasi pembeliannya, maka timbullah kepuasan nasabah dalam menggunakan produk-produk yang ditawarkan. Faktor-faktor yang mempengaruhi keputusan pembelian nasabah tidak lepas dari faktor marketing mix. Marketing mix merupakan rencana yang menyeluruh, terpadu, dan menyatu di bidang pemasaran, yang memberikan panduan tentang kegiatan yang akan dijalankan untuk dapat tercapainya tujuan pemasaran suatu perbankan yang meliputi produk, harga, lokasi, promosi, dan pelayanan. ${ }^{3}$

Kegiatan yang dijalankan oleh perbankan syariah baik berupa kegiatan operasional perbankan maupun kegiatan pemasaran didasarkan kepada syariat hukum Islam. Seperti yang tercantum dalam Al Qur'an surah AlJaatsiyah ayat 18 yang artinya "Kemudian Kami jadikan kamu berada di atas suatu syariat (peraturan) dari urusan (agama itu), Maka ikutilah syariat itu dan janganlah kamu ikuti hawa nafsu orang-orang yang tidak mengetahui". 4 Sehingga kegiatan perbankanpun harus didasarkan atas syariat agama Islam

Perbankan baik syariah maupun konvensional mempunyai berbagai macam kegiatan dalam menarik nasabah. Kegiatan penarikantersebut

2 Zamir Iqbal dan Abbas Mirakhor, Pengantar Keuangan Islam: Teori dan Praktek, terj. Oleh A.K. Anwar, Jakarta: Prenada Media Group, 2008, hlm. 373.

3 Sofjan Assauri, Manajemen Pemasaran: Dasar, Konsep, dan strategi, Jakarta: Raja Grafindo Persada, 2008, hlm. 169.

4 Departemen Agama RI, Al-Qur'an dan Terjemahannya, Jakarta: Proyek Pengadaan Kitab Suci Al-Qur'an DEPAG, 1995, hlm. 500. 
dilaksanakan agar calon nasabah bersedia menjadi nasabah suatu bank. Tidak hanya pihak bank yang melakukan kegiatan untuk menarik banyak nasabah, sebaliknya mereka terlebih dahulu juga meneliti produk-produk perbankan yang telah ditawarkan, akan tetapi mereka tidak akan menjadi nasabah jika kurang yakin terhadap produk yang ditawarkan. Disinilah bank perlu untuk mengadakan promosi yang terarah, karena diharapkan dapat memberikan pengaruh positif terhadap meningkatnya penjualan. ${ }^{5}$

Sejak dirumuskannya Undang-Undang Perbankan Syariah Nomor 21 Tahun 2017, pada Januari 2017 dengan nilai asset sebesar 11.6 trilyun rupiah, jumlah pembiayaan yang disalurkan mencapai 7.56 trilyun rupiah dan simpanan pihak ketiga sebesar 7.77 trilyun rupiah. ${ }^{6}$

Lahirnya Undang-Undang Perbankan Syariah mendorong peningkatan jumlah BUS, berikut disajikan pada tabel di bawah ini:

Perkembangan Bank Syariah Indonesia

\begin{tabular}{|c|c|c|c|c|c|c|c|c|c|c|}
\hline \multirow{3}{*}{$\begin{array}{c}\text { Indika } \\
\text { si }\end{array}$} & 199 & 201 & 201 & 201 & 201 & 201 & 201 & 201 & 201 & 201 \\
\cline { 2 - 12 } & KP/ & 7 & 6 & 1 & 2 & 3 & 4 & 5 & 6 & 7 \\
\hline KUS & 1 & 2 & KP/ & KP/ & KP/ & KP/ & KP/ & KP/ & KP/ & KP/ \\
\hline UUS & - & 8 & 15 & 19 & 20 & 25 & 22 & 22 & 21 & 21 \\
\hline BPRS & 76 & 84 & 88 & 92 & 105 & 114 & 163 & 163 & 166 & 167 \\
\hline
\end{tabular}

Sumber: BI, Statistik Perbankan Syariah, 2015

Keterangan:

BUS = Bank Umum Syariah, UUS = Unit Usaha Syariah, BPRS = Bank

Perkreditan Rakyat Syariah, KP/UUS = Kantor Pusat/ Unit Usaha

Syariah.

Berdasarkan penjelasan diatas dapat dilihat bahwa perkembangan perbankan syariah berdasarkan laporan tahunan BI Desember 2017. Secara kuantitas, pencapaian perbankan syariah sungguh membanggakan dan terus mengalami peningkatan dalam jumlah bank. Pada Desember 2017, jumlah bank syariah telah mencapai 13unit dan 21 unit usaha syariah. Selain itu, jumlah bank perkreditan rakyat syariah telah mencapai 167 unit pada periode yang sama.

Perbankan harus mampu mengenal apa yang menjadi kebutuhan dan harapan nasabah saat ini maupun yang akan datang. Nasabah sebagai individu dalam mendapatkan atau membeli barang telah melalui prosesproses atau tahapan-tahapan terlebih dahulu seperti mendapat informasi baik melalui iklan atau referensi dari orang lain kemudian membandingkan produk satu dengan produk lain sampai akhirnya pada keputusan membeli

${ }^{5}$ Endar Sugiyono, Pengaruh Persepsi Produk, Harga dan Promosi Terhadap Omset Penjualan pada Industri Keramik di Kec. Banjarharjo Kab. Brebes, UNNES, 2004, hlm. 17.

${ }^{6}$ Bank Indonesia, Statistik Perbankan Syariah, Jakarta: Indonesia. 
produk itu. Perilaku nasabah tersebut merupakan fenomena yang sangat penting dalam kegiatan pemasaran perbankan, yaitu perilaku nasabah dalam melakukan pembelian. ${ }^{7}$

Terdapat perbedaan penting antara sistem ekonomi Islam dengan sistem ekonomi kapitalis yang berpendapat bahwa permasalahan ekonomi yang sesungguhnya adalah kelangkaan (scarcity) barang dan jasa. ${ }^{8}$ Perbankan syariah sebagai alternatif dari sistem perbankan konvensional yang diharapkan dapat menggerakkan sektor riil (moneter based economy), karena itu perbankan syariah memerlukan pengaturan khusus. Aturan tersebut harus dapat menampung berbagai kepentingan tidak saja umat Islam, tetapi juga non-muslim karena perbankan syariah bersifat universal. Seperti layaknya sebuah produk barang, perbankan syariah mulai diminati oleh semua kalangan konsumen di Indonesia. Konsumen mempunyai alasanalasan tertentu atau faktor-faktor yang mempengaruhi mereka untuk mengambil keputusan dalam menetapkan pilihan pada bank syariah.

Dalam penelitian kali ini, penulis memilih Bank Muamalat sebagai obyek penelitian karena Bank Muamalat merupakan salah satu perusahaan perbankan yang mengaplikasikan sistem syariah (dual banking system). Dalam perjalanannya, pertumbuhan nasabah di Bank Muamalat tidak hanya terdiri kaum muslim saja, akan tetapi dari kalangan Non-Muslimpun banyak yang menjadi nasabah di Bank Muamalat. Berdasarkan pengamatan di lapangan menunjukkan bahwa salah satu alasan terkait pengambilan keputusan masyarakat memilih untuk menjadi nasabah bank syariah adalah terkait produk, pelayanan dan promosi yang diberikan oleh Bank Muamalat.

Berdasarkan uraian di atas, maka penelitian ini bertujuan untuk mengetahui apakah produk, pelayanan dan promosi secara parsial berpengaruh terhadap keputusan nasabah untuk menabung di Bank Muamalat Indonesia dan untuk mengetahui apakah produk, pelayanan dan promosi secara simultan berpengaruh terhadap keputusan nasabah untuk menabung di Bank Muamalat Indonesia. Penelitian ini merupakan penelitian yang berbasis studi lapangan dengan pendekatan kuantitatif deskriptif dengan metode analisis regresi linear berganda yang dilaksanakan di Bank Muamalat Indonesia Kota Jambi. Intrumen pengumpulan data dalam penelitian ini adalah kuisioner dan wawancara yang diberikan kepada sampel berjumlah 100 nasabah.

\section{Pemaknaan Produk}

Secara luas produk (product) adalah segala sesuatu yang dapat ditawarkan kepada pasar untuk memuaskan suatu keinginan atau kebutuhan, termasuk barang fisik, jasa, pengalaman, acara, orang, tempat, property, organisasi,

${ }^{7}$ S wastha Bashu, Azas-Azas Marketing, Edisi Ketiga, Yogyakarta: Liberty Offset, 2003, hlm. 201.

${ }^{8}$ Sukirno, Ekonomi Kapitalis, Yogyakarta: Elex Media Yogyakarta, 2015, hlm. 28. 
informasi dan ide. ${ }^{9}$ Produk juga diartikan sebagai sesuatu yang dapat ditawarkan kepada pasar agar menarik perhatian, akuisisi, penggunaan, atau konsumsi yang dapat memuaskan suatu keinginan atau kebutuhan. ${ }^{10}$ Pada dasarnya produk yang dibeli konsumen itu dapat dibedakan atas tiga tingkatan, yaitu : 1) Produk inti (core product), 2) Produk formal (formal product), 3) Produk tambahan (augmented product).

Berdasarkan daya tahan dan wujud tidaknya produk yang dihasilkan, maka produk dapat diklasifikasikan ke dalam tiga kelompok yakni barang tidak tahan lama, barang tahan lama dan jasa. Barang tidak tahan lama atau sering disebut barang yang terpakai habis (Non Durable Goods) adalah barang berwujud yang secara normal biasanya dikonsumsi dalam satu atau beberapa kali penggunaan. Sementara barang tahan lama (Durable Goods) adalah barang berwujud yang biasanya secara normal dapat bertahan lama sehingga dapat digunakan dalam banyak pemakaian. Kemudian jasa (Service) adalah suatu aktifitas, manfaat atau kepuasan yang ditawarkan untuk dijual.

Sedangkan kebiasaan konsumen dapat diklasifikasikan ke dalam empat golongan yakni: Convinience Goods, Shopping Goods, Specialty Goods, Unsought Goods. ${ }^{11}$ Deming dalam buku karangan M.N Nasution yang berjudul Manajemen Mutu Terpadu Total Quality Management, menjelaskan terkait kualitas adalah kesesuaian dengan kebutuhan pasar atau konsumen. Perusahaan harus benar-benar dapat memahami apa yang dibutuhkan konsumen atas suatu produk yang akan dihasilkan. ${ }^{12}$

Kualitas produk (product quality) adalah karakteristik produk atau jasa yang bergantung pada kemampuannya untuk memuaskan kebutuhan pelanggan yang dinyatakan atau diimplikasikan. ${ }^{13}$ Sedangkan menurut Prawirosentono dalam bukunya Filosofi Baru Tentang Manajemen Mutu Terpadu, kualitas atau mutu suatu produk adalah keadaan fisik, fungsi, dan sifat suatu produk bersangkutan yang dapat memenuhi selera dan kebutuhan konsumen dengan memuaskan sesuai nilai uang yang telah dikeluarkan. ${ }^{14}$

Secara umum dimensi spesifikasi mutu produk dapat dibagi sebagai berikut :a) Kinerja (Performance) Kinerja suatu produk harus dicantumkan pada labelnya, misalnya isi, berat, kekentalan, komposisi, kekuatan dalam putaran, serta lama hidup penggunaan. Misalnya, susu kaleng atau minuman ringan tercantum volumenya; b) Keistimewaan (Types of Features) Produk bermutu yang mempunyai keistimewaan khusus dibandingkan dengan 2, hlm. 4.

9 Philip Kotler dan Kevin Lane Keller, Manajemen Pemasaran, Edisi Ketiga Belas, Jilid

10 Philip Kotler dan Gary Armstrong, Prinsip-Prinsip Pemasaran, Edisi 12, Jilid 1, Jakarta: Erlangga, 2006, hlm. 266.

11 Marius, P Angipora, Dasar-Dasar Pemasaran, Jakarta : Raja Grafindo Persada, 2015, hlm. 160 - 165.

12 Manajemen Mutu Terpadu Total Quality Management, Jakarta: Rosda Karya, 2012, hlm. 27.

13 Philip Kotler dan Gary Armstrong, hlm. 272.

14 Suyadi Prawirosentono, Filosofi Baru Tentang Manajemen Mutu Terpadu, Jakarta: Bumi Aksara, 2017, hlm 6. 
produk lain. Misalnya, konsumen pembeli TV sering mencari yang mempunyai keistemewaan seperti suara stereo, tingkat resolusi tinggi; c) Kepercayaan dan waktu (Reliability and Durability) Produk yang bermutu baik adalah produk yang mempunyai kinerja yang konsisten baik dalam batas-batas perawatan normal. Misalnya, oli mesin yang baik mempunyai kepekatan dan kekentalan yang memadai dan berjangka $5.000 \mathrm{~km}$ (Durability); d) Mudah dirawat dan diperbaiki (Maintainability and Serviceability) Produk bermutu baik harus pula memenuhi kemudahan untuk diperbaiki atau dirawat. Misalnya, sepeda motor yang baik mudah dirawat oleh setiap montir (mekanik) karena tersedia suku cadang di pasar bebas; e) Sifat khas (Sensory Characteristic) Untuk beberapa jenis produk mudah dikenal dari wanginya, bentuknya, rasanya, atau suaranya. Misalnya, TV Sony dilihat dari penampilan dan daya tahannya, dan radio merk JVC ditandai dengan suara yang bening; f) Penampilan dan Citra Etis, dimensi lain dari produk yang bermutu adalah persepsi konsumen atas suatu produk. Misalnya, ramah dan cepatnya pelayanan British Columbia Telecom (Kanada) terhadap para konsumen. ${ }^{15}$

\section{Kualitas Jasa Pelayanan}

Menurut American Society for Quality Control "kualitas jasa adalah keseluruhan ciri serta sifat dari suatu produk atau pelayanan yang berpengaruh pada kemampuannya untuk memuaskan kebutuhan yang dinyatakan atau yang tersirat". ${ }^{16}$ Beberapa pengertian yang terkait dengan kualitas jasa pelayanan yaitu: ${ }^{17}$ 1) Excellent: standar kinerja yang diperoleh; 2) Customer: perorangan, kelompok, departemen, atau perusahaan yang menerima, membayar output pelayanan (jasa atau sistem); 3) Service: kegiatan utama atau pelengkap yang tidak secara langsung terlibat dalam proses pembuatan produk tetapi lebih menentukan pada pelayanan transaksi antara pembeli dan penjual; 4) Quality: sesuatu yang secara khusus dapat diraba atau tidak dapat diraba dari sifat yang dimiliki produk atau jasa; 5) Consistens: tidak memiliki variasi dan semua pelayanan berjalan sesuai dengan standar yang telah ditetapkan; 6) Levels: suatu pernyataan atas sistem yang digunakan untuk memonitor dan mengevaluasi; 7) Delivery: memberikan pelayanan yang benar dengan cara dan waktu yang tepat.

Berdasarkan beberapa pengertian di atas dapat ditarik kesimpulan bahwa kualitas pelayanan adalah suatu kondisi yang berhubungan dengan produk dan jasa untuk memenuhi kebutuhan dan keinginan pelanggan serta ketepatannya untuk mengimbangi harapan pelanggan.

Lima dimensi utama kualitas jasa, diantaranya: ${ }^{18}$ 1) Bukti Langsung (tangibles), meliputi fasilitas fisik, perlengkapan, pegawai dan sarana

\footnotetext{
16 Kotler, Philip, Manajemen Pemasarn, Jakarta: Indeks 2007, hlm. 180.

17 Kamir, Bank dan Lembaga Keuangan Lainnya, Jakarta: Raja Grafindo, 2016. hlm 22.

18 Kamir, hlm. 22.
} 
komunikasi; 2) Kehandalan (reliability), yakni kemampuan memberikan pelayanan yang dijanjikan dengan segera dan memuaskan; 3) Daya tanggap (responsiveness), yaitu keinginan para staf untuk membantu pelanggan dan memberikan pelayanan dengan tanggap; 4) Jaminan (assurance), yakni mencakup kemampuan, kesopanan dan sifat dapat dipercaya yang dimiliki para staf, bebas dari bahaya, risiko atau keragu-raguan; 5) Empati (emphaty), meliputi kemudahan dalam melakukan hubungan, komunikasi yang baik dan memahami kebutuhan para pelanggan.

Tujuan dari suatu bisnis adalah untuk menciptakan kepuasan para pelanggan, salah satunya melalui kualitas pelayanan. Terciptanya kepuasan pelanggan terhadap kualitas pelayanan dapat memberikan manfaat di antaranya hubungan antara perusahaan dan pelanggan menjadi harmonis, memberikan dasar yang baik bagi pembelian ulang dan terciptanya loyalitas pelanggan dan membentuk suatu rekomendasi dari mulut ke mulut yang menguntungkan bagi perusahaan. ${ }^{19}$

Salah satu pendekatan kualitas pelayanan yang banyak dijadikan acuan dalam riset pemasaran adalah model Servqual (Service Quality) yang dikembangkan oleh Parasuraman, Zeithaml dan Berry dalam serangkaian penelitian mereka terhadap enam sektor jasa yaitu reparasi, peralatan rumah tangga, kartu kredit, asuransi, sambungan telepon jarak jauh, serta perbankan ritel dan pialang sekuritas. ${ }^{20}$ Berdasarkan penjelasan di atas, maka dapat disimpulkan bahwa pelayanan merupakan bagian dari suatu tindakan atau perbuatan seseorang atau organisasi untuk memberikan kepuasan kepada pelanggan.

\section{Pelayanan dalam Perspektif Islam}

Dalam pandangan Islam, pelayanan mempunyai nilai-nilai islami yang harus diterapkan dalam memberikan pelayanan yang maksimal seperti mewujudkan dari kata profesional (Fathanaah), kesopanan dan keramahan (Tabligh), Jujur (Sidik) dan amanah yang dijelaskan sebagai berikut: a) Profesional adalah bekerja dengan maksimal dan penuh komitmen dan kesungguhan. ${ }^{21}$ Sifat profesionalisme digambarkan dalam surat Al-Isra ayat 84 yang artinya merupakan " katakanlah: Tiap-tiap orang berbuat menurut keadaannya masing-masing. Maka Tuhanmu lebih mengetahui siapa yang lebih benar jalanNya22"; b) Tabligh artinya komunikatif dan argumentatif. Orang memiliki sifat tabligh akan menyampaikan dengan benar dan tutur

19 Tjiptono, Fandi, Strategi Pemasaran, Yogyakarta: CV. Andi Offset, 2008, hlm. 24.

20 Lupiyoadi, Rambat dan Hamdani, A. Manajemen Pemasaran Jasa, Edisi Kedua, Jakarta: Salemba Empat, 2011, hlm. 181.

${ }^{21}$ Didin Hafidudin dan Hendri Tanjung, Manajemen Pemasaran Syariah dalam Praktik, Jakarta: Gema Insani Inpress, 2003, hlm. 63.

22 Departemen Agama, alquran dan terjemahannya, Jakarta, Bumi Aksara, hlm 290. 
kata yang tepat. ${ }^{23}$ Kesopanan dan keramahan merupakan pelayanan kepada orang lain. Hal ini ditegaskan dalam Al-Qur'an surat Thaha 44 yang artinya adalah sebagai berikut "Maka berbicaralah kamu berdua kepadanya dengan kata-kata yang lemah lembut, Mudah-mudahan ia ingat atau takut"24; c) Jujur yaitu tidak pernah berdusta dalam melakukan segala kegiatan transaksi. Jujur juga merupakan kesesuaian antar berita yang disampaikan dan fakta, antara fenomena dan yang diberitakan, serta bentuk dan substansi; dan d) Amanah berarti memiliki tanggung jawab dalam melaksanakan tugas dan kewajiban. Allah SWT berfirman dalam sutat An-Nisa ayat 58 yang artinya adalah "Sesungguhnya Allah menyuruh kamu menyampaikan amanat kepada yang berhak menerimanya, dan (menyuruh kamu) apabila menetapkan hukum di antara manusia supaya kamu menetapkan dengan adil. Sesungguhnya Allah memberi pengajaran yang sebaik-baiknya kepadamu. Sesungguhnya Allah adalah Maha mendengar lagi Maha melihat. ${ }^{25}$

Berdasarkan penjelasan di atas, maka dapat disimpulkan bahwa kualitas pelayanan adalah suatu kondisi yang berhubungan dengan produk dan jasa untuk memenuhi kebutuhan dan keinginan pelanggan serta ketepatannya untuk mengimbangi harapan pelanggan dengan indikatorindikator Profesional (Fathanaah), Kesopanan dan Keramahan (Tabligh), Jujur (Sidik), dan amanah.

\section{Promosi Produk}

Promosi adalah sarana yang paling ampuh untuk menarik dan mempertahankan konsumennya. ${ }^{26}$ Promosi adalah suatu teknik komunikasi yang dirancang untuk menstimulasi konsumen membeli. Tujuan dari promosi adalah untuk meningkatkan penjualan. ${ }^{27} \mathrm{Hal}$ yang harus diperhatikan dalam bauran promosi adalah dengan cara melihat iklan, atau suatu promosi penjualan yang berbentuk kontes, permaianan, undian lotre dan sebagainya, acara dan pengalaman dimana disponsori oleh perusahaan serta hubungan masyarakat dan publisitas pemasaran langsung, serta pemasaran terkatif atau dengan pemasaran dari mulut kemulut, atau dengan melakukan penjualan personal melaui tatap muka dengan satu atau lebih.

Ekonomi Islam juga menerapkan promosi yang dilakukan untuk menawarkan, menginformasikan, menjual produk atau jasa di pasar. karena dengan promosi masyarakat akan mengetahui keberadaan produk atau jasa. Konsep Al-Qur'an tentang bisnis juga sangat komprehensif, parameter yang dipakai tidak menyangkut dunia saja, namun juga menyangkut urusan akhirat. Al-Qur'an memandang kehidupan manusia sebagai sebuah proses hlm. 132

${ }^{23}$ Hermawan Kartajaya dan M. Syakir Sula, Syariah Marketing, Bandung: Mizan, 2006,

${ }^{24}$ Departemen Agama, alquran dan terjemahannya, Jakarta: Bumi Aksara, hlm. 314.

${ }^{25}$ Departemen Agama, alquran dan terjemahannya, Jakarta: Bumi Aksara, hlm. 87.

${ }^{26}$ Kasmir, Kewirausahaan, Jakarta: Raja Grafido Persada, 2014, hlm.198.

27 Rhenald kasali, Modul Kewirausahaan, Jakarta: Mizan Publika, 2010. hlm. 156. 
yang berkelanjutan. Manusia harus bekerja bukan hanya untuk meraih sukses di dunia namun juga kesuksesan di akhirat. ${ }^{28}$

\section{Keputusan Pelanggan untuk Menabung}

Perusahaan yang cerdas akan berusaha untuk memahami proses keputusan pembelian pelanggan secara penuh yaitu tentang semua pengalaman pelanggan dalam pembelajaran, memilih, menggunakan dan bahkan menyingkirkan produk. ${ }^{29}$

Pengambilan keputusan merupakan suatu kegiatan individu yang secara langsung terlibat dalam mendapatkan dan mempergunakan barang yang ditawarkan. Tahap-tahap proses keputusan pembelian dapat digambarkan dalam sebuah model di bawah ini ${ }^{30}$ :

Tahap Proses Pembelian

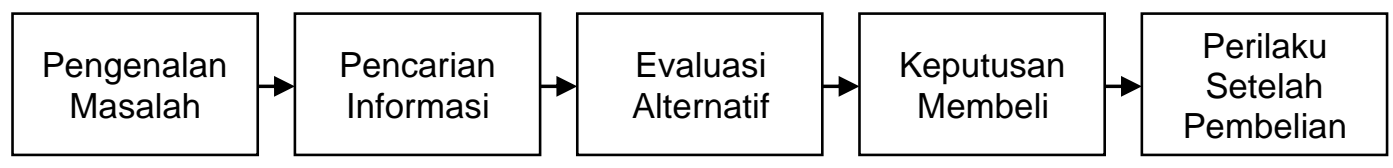

Model tersebut mempunyai implikasi bahwa para konsumen melalui lima tahap dalam membeli sesuatu. Tahap-tahap tersebut tidak harus dilewati secara urut. Dalam pemecahan masalah pembelian yang bersifat ekstensif calon pembeli dapat bertolak dari keputusan mengenai penjual, karena ia ingin mendapat keterangan dari penjual yang dipercaya, mengenai perbedaan dan bentuk produk. Keputusan pembelian merupakan suatu proses penyelesaian masalah pembelian produk yang terdiri dari pengenalan masalah, pencarian informasi, evaluasi alternatif, keputusan pembelian dan perilaku.

Beberapa faktor yang mempengaruhi nasabah untuk menabung adalah:

1) Faktor Marketing Mix

Para pemasar menggunakan sejumlah alat untuk mendapatkan tanggapan yang diinginkan dari pasar sasaran mereka, alat-alat itu membentuk suatu bauran pemasaran. Dalam pandangan Lamb, Hair dan McDaniel bauran pemasaran mengacu pada paduan strategi produk, distribusi, promosi, dan penentuan harga yang bersifat unik yang dirancang untuk menghasilkan pertukaran yang saling memuaskan dengan pasar yang dituju. ${ }^{31}$

Menurut Kotler dan Armstrong pengertian marketing mix adalah seperangkat alat pemasaran yang digunakan perusahaan untuk terus-

${ }^{28}$ Ahmad Mustag, The Furture of Economics: An Islamic Perspektif, Jakarta: Asy Syaamil Press \& Grafika, 2017, hlm. 35.

29 Kotler, Philip dan Keller, Kevin Lane, Manajemen Pemasaran, Jakarta: Erlangga, 2009, Hlm. 184.

${ }^{30}$ Kotler, Philip, Manajemen Pemasaran, Jakarta: Prehallindo, 2015, hlm. 202.

${ }^{31}$ Lamb, C. W., Hair, J. F., \& McDaniel, C, Essentials of Marketing, Boston: Cengage Learning, hlm. 125. 
menerus mencapai tujuan pemasarannya di pasar sasaran. ${ }^{32}$ Jika sasaran pasarnya sudah ditentukan melalui riset pemasaran, maka perusahaan harus membuat suatu rencana yang baik untuk memasuki segmen pasar yang dipilih. Keputusan-keputusan dalam pemasaran dapat dikelompokkan dalam beberapa indikator, yaitu: a) Produk. Pengertian produk bagi konsumen selain merupakan benda yang mempunyai manfaat dan kegunaan juga merupakan suatu yang dapat ditawarkan ke pasar untuk mendapatkan perhatian untuk dibeli, digunakan atau dikonsumsi yang dapat memenuhi suatu kegiatan atau kebutuhan. Pengembangan sebuah produk menghasilkan perusahaan menetapkan manfaat-manfaat apa yang akan diberikan produk itu. Manfaat ini dikomunikasikan dan hendaknya dipenuhi oleh atribut produk; b) Harga. Harga adalah faktor utama yang harus ditentukan sebelum suatu produk diluncurkan ke pasar sasaran. Harga produk juga salah satu faktor penentu bagi permintaan pasar yang secara otomatis akan mempengaruhi volume penjualan. Jika harga produk tidak dapat dijangkau konsumen, maka target penjualan yang telah ditetapkan tidak tercapai. Harga menurut Umar adalah sejumlah nilai yang ditukarkan konsumen dengan manfaat dari memiliki atau menggunakan produk atau jasa yang nilainya ditetapkan oleh pembeli dan penjual melalui tawar menawar atau ditetapkan oleh penjual untuk satu harga yang sama terhadap semua pembeli33; c) Distribusi. Suatu pemasaran perusahaan dimulai dari distribusi, namun fungsi place komponen place memegang peranan yang sangat penting dalam pemasaran. Place atau kalau diterjemahkan bisa berarti penempatan produk, distribusi atau penyebaran produk yang sangat menentukan keberhasilan pemasaran. Suatu produk atau jasa didistribusikan oleh principal secara terencana. Perusahaan berusaha agar produk atau jasa dapat tersebar melalui channel-channel pemasaran. Strategi distribusi ini dilakukan melalui penggunaan sales force yang cukup banyak. Setelah produk atau jasa tersebar barulah perusahaan mendorong dengan promosi. Sistem distribusi ini dikenal dengan sistem push distribution; d) Promosi. Pemasaran tidak hanya membicarakan mengenai produk, harga produk dan mendistribusikan produk, tetapi juga mengkomunikasikan produk ini kepada masyarakat agar produk itu dikenal dan ujung-ujungnya dibeli. Menurut Boyd, Walker, dan Larreche menyatakan strategi promosi merupakan sebuah program terkendali dan terpadu dari metode komunikasi dan material yang dirancang untuk menghadirkan perusahaan dan produk-produknya kepada calon konsumen, menyampaikan ciri-ciri produk yang memuaskan kebutuhan untuk mendorong penjualan yang pada akhirnya memberikan kontribusi pada kinerja laba jangka panjang. ${ }^{34}$ Menurut Swastha (2007) promosi adalah arus informasi atau persuasi satu arah yang dibuat untuk menciptakan

${ }^{32}$ Kotler, P., \& Armstrong, G.,Principles of Marketing, New Jersey: Pearson Education, hlm. 89.

33 Umar, Husein, Riset Pemasaran dan Perilaku Konsumen, Jakarta: Gramedia Pustaka Utama, hlm. 32. hlm. 65 .

${ }^{34}$ Boyd, H. W., Walker, O. C., \& Larreche, J. C, Manajemen Pemasaran, Jakarta: Erlangga, 
pertukaran dalam pemasaran. Selain juga harus memperkerjakan, melatih dan memotivasi wiraniaganya. ${ }^{35}$

2. Faktor Budaya

Budaya menurut Kotler dan Armstrong adalah merupakan penentu keinginan dan perilaku yang paling mendasar. ${ }^{36}$ Menurut Lamb, Hair dan McDaniel budaya adalah karakter yang penting dari suatu sosial yang membedakannya dari kelompok kultur yang lainnya. ${ }^{37}$

3. Faktor Sosial

Faktor sosial terbagi menjadi beberapa indikator, yaitu: a) Kelompok acuan yaitu kelompok yang memiliki pengaruh langsung (tatap muka) atau tidak langsung terhadap sikap atau perilaku seseorang. ${ }^{38}$ Orang sangat dipengaruhi oleh kelompok acuan mereka sekurang-kurangnya melalui tiga jalur: Kelompok acuan menghadapkan seseorang pada perilaku dan gaya hidup baru. Kelompok acuan juga mempengaruhi perilaku dan konsep pribadi seseorang; b) Keluarga menurut Kotler dan Armstrong merupakan organisasi pembelian konsumen yang paling penting dalam masyarakat dan ia telah menjadi objek penelitian yang luas. Anggota keluarga merupakan kelompok acuan primer yang paling berpengaruh. Menurut Lamb, Hair dan McDaniel keluarga merupakan institusi sosial yang paling penting bagi beberapa konsumen, karena secara kuat mempengaruhi nilai, sikap, konsep pribadi, dan perilaku pembelian ${ }^{39}$ : c) Peran dan status maksudnya adalah seseorang berpartisipasi ke dalam banyak kelompok sepanjang hidupnya, keluarga, klub, organisasi. Kedudukan orang itu di masing-masing kelompok dapat ditentukan berdasarkan peran dan status. Peran merupakan kegiatan yang diharapkan dilakukan oleh seseorang. Status merupakan masingmasing dari peran tersebut akan menghasilkan status.

4. Faktor Pribadi

Keputusan pembelian juga dipengaruhi karakteristik pribadi yang terdiri dari: a) Usia dan Tahap Siklus Hidup; b) Gaya Hidup; c) Kepribadian dan Konsep Diri

5. Faktor Psikologis

Pilihan pembelian konsumen dipengaruhi oleh empat faktor psikologis, yang terdiri dari: a) Motivasi; b) Persepsi; c) Pembelajaran; d) Keyakinan dan Sikap.

\footnotetext{
35 Boyd, H. W., Walker, O. C., \& Larreche, J. C, hlm. 65.

36 Kotler dan Armstrong, hlm.127.

${ }^{37}$ Lamb, Hair, hlm. 91.

38 Kotler dan Armstrong, hlm. 130.

${ }^{39}$ Lamb, Hair, hlm. 97.
} 


\section{Pengaruh Produk terhadap Keputusan Menabung di Bank Muamalat Kota Jambi}

Penelitian menunjukkan bahwa nasabah menanggapi dengan sangat baik produk yang ditawarkan oleh Bank Muamalat Indonesia Kota Jambi. Hal ini ditunjukkan oleh tingginya respon nasabah terhadap semua butir-butir pernyataan yang diberikan, rata-rata skor tanggapan nasabah adalah sebesar 4,35. Skor ini berada pada rentang 4,21-5,00 dengan kategori sangat baik. Hal ini menunjukkan bahwa nasabah menganggap bahwa produk yang ditawarkan Bank Muamalat Indonesia Kota Jambi sangat baik, yang ditandai dengan penilaian terhadap kualitas produk yang sangat baik, produk yang ditawarkan juga memiliki ciri yang khas, dan model produk yang ditawarkan mampu menarik minat nasabah.

Hasil uji parsial menunjukkan bahwa produk berpengaruh positif dan signifikan terhadap keputusan nasabah untuk menabung pada Bank Muamalat Indonesia Kota Jambi. Hal ini ditunjukkan oleh nilai thitung untuk variabel produk, diketahui bahwa thitung $(6,055)>t_{\text {tabel }}(1,975)$, dan nilai signifikansi sebesar 0,000 $<0,050$, maka penelitian ini berhasil menolak $\mathrm{H}_{0}$ yang menyatakan bahwa variabel produk tidak berpengaruh terhadap keputusan nasabah untuk menabung di Bank Muamalat Indonesia Kota Jambi dan menerima $\mathrm{H}_{1}$ yang menyatakan bahwa variabel produk berpengaruh terhadap keputusan nasabah untuk menabung di Bank Muamalat Indonesia Kota Jambi.

Sedangkan Koefisien regresi variabel produk ( $\left.\mathrm{X}_{1}\right)$ sebesar 0,753 artinya jika produk mengalami peningkatan satu satuan, maka keputusan nasabah untuk menabung pada Bank Muamalat Indonesia Kota Jambi akan mengalami peningkatan sebesar 0,753 satuan. Koefisien bernilai positif artinya antara produk dan keputusan nasabah untuk menabung pada Bank Muamalat Indonesia Kota Jambi terdapat hubungan yang positif. Peningkatan produk akan mengakibatkan peningkatan pada keputusan nasabah untuk menabung pada Bank Muamalat Indonesia Kota Jambi.

\section{Pengaruh Pelayanan terhadap Keputusan Menabung di Bank Muamalat Indonesia Kota Jambi}

Hasil penelitian menunjukkan bahwa nasabah menanggapi dengan sangat baik pelayanan yang diberikan oleh Bank Muamalat Indonesia Kota Jambi. Profesionalitas (Fathanah) pegawai Bank Muamalat Indonesia Kota Jambi yang ditunjukkan oleh kemampuan pegawai untuk bekerja dengan maksimal dan penuh komitmen dan kesungguhan sudah dilakukan dengan sangat baik. Hal ini ditandai oleh tanggapan nasabah yang menilai bahwa pelayanan BMI Cepat, tepat, dan sesuai serta terpercaya serta melayani dengan salam, senyum, sapa, sopan, ramah, dan nyaman sudah dilakukan dengan sangat baik.. Rata-rata skor tanggapan nasabah terhadap kuesioner yang menggambarkan tanggapan nasabah terhadap pelayanan Bank Muamalat Indonesia Kota Jambi adalah sebesar 4,55. Skor ini berada pada rentang 4,21- 
5,00. Hal ini menunjukkan bahwa nasabah menganggap bahwa pihak Bank sudah bekerja sangat profesional, sangat sopan dalam melayani nasabah, menyampaikan informasi dengan sangat jujur, dan sangat bertanggung jawab dalam melaksanakan tugasnya.

Hasil uji parsial menunjukkan bahwa pelayanan berpengaruh positif dan signifikan terhadap keputusan nasabah untuk menabung pada Bank Muamalat Indonesia Kota Jambi. Hal ini ditunjukkan oleh nilai thitung untuk variabel pelayanan, diketahui bahwa thitung $(6,045)>t_{\text {tabel }}(1,975)$, dan nilai signifikansi sebesar $0,000<0,050$, maka penelitian ini berhasil menolak $\mathrm{H}_{0}$ yang menyatakan bahwa variabel pelayanan tidak berpengaruh terhadap keputusan nasabah untuk menabung di Bank Muamalat Indonesia Kota Jambi dan menerima $\mathrm{H}_{1}$ yang menyatakan bahwa variabel layanan berpengaruh terhadap keputusan nasabah untuk menabung di Bank Muamalat Indonesia Kota Jambi. Artinya layanan berpengaruh signifikan terhadap keputusan nasabah untuk menabung di Bank Muamalat Indonesia Kota Jambi. Nilai $t_{\text {hitung }}$ bertanda positif, artinya peningkatan layanan akan menyebabkan peningkatan pada keputusan nasabah untuk menabung di Bank Muamalat Indonesia Kota Jambi, demikian pula sebaliknya.

Sedangkan Koefisien regresi variabel pelayanan $\left(\mathrm{X}_{2}\right)$ sebesar 0,534 artinya jika pelayanan mengalami peningkatan satu satuan, maka keputusan nasabah untuk menabung pada Bank Muamalat Indonesia Kota Jambi akan mengalami peningkatan sebesar 0,534 satuan. Koefisien bernilai positif artinya antara pelayanan dan keputusan nasabah untuk menabung pada Bank Muamalat Indonesia Kota Jambi terdapat hubungan yang positif. Peningkatan pelayanan akan mengakibatkan peningkatan pada keputusan nasabah untuk menabung pada Bank Muamalat Indonesia Kota Jambi.

\section{Pengaruh Promosi terhadap Keputusan Menabung di Bank Muamalat Indonesia Kota Jambi}

Hasil penelitian menunjukkan bahwa nasabah menanggapi dengan sangat baik promosi yang dilakukan oleh Bank Muamalat Indonesia Kota Jambi.. Rata-rata skor tanggapan nasabah terhadap kuesioner yang menggambarkan tanggapan nasabah terhadap promosi yang dilakukan oleh Bank Muamalat Indonesia Kota Jambi adalah sebesar 4,28. Skor ini berada pada rentang 4,215,00 . Hal ini menunjukkan bahwa nasabah menganggap pihak Bank menggunakan sarana periklanan untuk menginformasikan produk dengan sangat baik, melakukan promosi penjualan dengan sangat baik, dan menyampaikan produk perbankan kepada calon nasabah dengan sangat baik.

Hasil uji parsial menunjukkan bahwa promosi berpengaruh positif dan signifikan terhadap keputusan nasabah untuk menabung pada Bank Muamalat Indonesia Kota Jambi. Hal ini ditunjukkan oleh nilai thitung untuk variabel promosi, diketahui bahwa thitung $(2,696)>t_{\text {tabel }}(1,975)$, dan nilai signifikansi sebesar 0,008 $<0,050$, maka penelitian ini berhasil menolak $\mathrm{H}_{0}$ yang menyatakan bahwa variabel promosi tidak berpengaruh terhadap keputusan nasabah untuk menabung di Bank Muamalat Indonesia Kota Jambi 
dan menerima $\mathrm{H}_{1}$ yang menyatakan bahwa variabel promosi berpengaruh terhadap keputusan nasabah untuk menabung di Bank Muamalat Indonesia Kota Jambi. Artinya promosi berpengaruh signifikan terhadap keputusan nasabah untuk menabung di Bank Muamalat Indonesia Kota Jambi. Sedangkan Koefisien regresi variabel promosi $\left(\mathrm{X}_{3}\right)$ sebesar 0,266 artinya jika promosi mengalami peningkatan satu satuan, maka keputusan nasabah untuk menabung pada Bank Muamalat Indonesia Kota Jambi akan mengalami peningkatan sebesar 0,266 satuan.

\section{Pengaruh Produk, Pelayanan, dan Promosi terhadap Keputusan Menabung di Bank Muamalat Indonesia Kota Jambi.}

Hasil penelitian menunjukkan bahwa nasabah menyambut dengan sangat baik produk tabungan yang ditawarkan oleh Bank Muamalat Indonesia Kota Jambi. Hal ini terlihat dari produk yang ditawarkan sudah dikenal dengan sangat baik oleh nasabah. Rata-rata skor tanggapan nasabah terhadap kuesioner yang menggambarkan keputusan nasabah untuk menabung adalah sebesar 4,37. Skor ini berada pada rentang 4,21-5,00. Hal ini menunjukkan bahwa nasabah memiliki sangat mengenal kebutuhan untuk menabung di Bank Muamalat Indonesia Kota Jambi, mampu mengumpulkan informasi mengenai produk yang ditawarkan, memiliki evaluasi alternatif dengan memproses informasi yang diperoleh, dapat memutuskan untuk menggunakan produk yang ditawarkan, dan tidak memiliki konflik setelah menggunakan produk perbankan.

Hasil uji regresi menunjukkan nilai konstan sebesar 2,177 dan bertanda positif menunjukkan bahwa jika nilai produk, pelayanan, dan promosi tetap, maka keputusan nasabah untuk menabung pada Bank Muamalat Indonesia Kota Jambi adalah sebesar 2,177 satuan.

Hasil uji simultan menunjukkan bahwa secara simultan variabel produk, pelayanan, dan promosi berpengaruh positif dan signifikan terhadap keputusan menabung di Bank Muamalat Indonesia Kota Jambi. Hal ini


signifikansi $F_{\text {hitung }}$ 0,000. Karena $F_{\text {hitung }}(1806,297)>F_{\text {tabel }}(2,70)$, maka $\mathrm{H}_{1}$ diterima, artinya variabel variabel produk, pelayanan, dan promosi berpengaruh terhadap keputusan nasabah untuk menabung di Bank Muamalat Indonesia Kota Jambi. Nilai Fhitung bertanda positif, artinya peningkatan produk, pelayanan, dan promosi secara simultan akan menyebabkan peningkatan pada keputusan nasabah untuk menabung di Bank Muamalat Indonesia Kota Jambi, demikian pula sebaliknya.

Koefisien determinasi yang digunakan untuk mengukur derajat hubungan antara variabel produk, pelayanan, dan promosi terhadap keputusan nasabah untuk menabung di Bank Muamalat Indonesia Kota Jambi menunjukkan nilai koefisien determinasi sebesar 0,983. Artinya bahwa variabel-variabel produk, pelayanan, dan promosi secara simultan mampu menjelaskan keputusan nasabah untuk menabung di Bank Muamalat Indonesia Kota Jambi sebesar 98,3 persen, sedangkan sisanya sebesar 1,7 
persen dijelaskan oleh variabel lain yang tidak disertakan dalam pengujian. Nilai $\mathrm{R}^{2}$ sebesar 98,3 persen menunjukkan bahwa variabel produk, pelayanan, dan promosi sangat mampu menjelaskan keputusan nasabah untuk menabung di Bank Muamalat Indonesia Kota Jambi.

\section{Penutup}

Hasil penelitian menunjukkan bahwa nasabah menanggapi dengan sangat baik terhadap produk yang ditawarkan dengan rata-rata skor sebesar 4,35, pelayanan yang diberikan dengan rata-rata skor sebesar 4,55, dan promosi yang dilaksanakan dengan rata-rata skor sebesar 4,28 sehingga nasabah juga menanggapi dengan sangat baik terhadap keputusan untuk menabung di Bank Mauamalat Indonesia Kota Jambi dengan rata-rata skor sebesar 4,37. Ada faktor loyalitas nasabah lama yang merupakan sampel penelitian ini, sehingga tanggapan atas produk yang ditawarkan, pelayanan yang diberikan, promosi yang dilaksanakan dan keputusan untuk menabung berbanding terbalik dengan jumlah rekening dana funding Bank Mauamalat Indonesia Kota Jambi yang mengalami penurunan sejak periode 2013-2017.

Hasil penelitian menunjukkan bahwa secara parsial variabel produk dengan nilai thitung $(6,055)>t_{\text {tabel }}(1,975)$, dan nilai signifikansi sebesar 0,000 $<0,050$, variabel pelayanan dengan nilai thitung $(6,045)>t_{\text {tabel }}(1,975)$, dan nilai signifikansi sebesar $0,000<0,050$, dan promosi dengan nilai thitung $(2,696)>$ tabel $(1,975)$, dan nilai signifikansi sebesar 0,008 $<0,050$ berpengaruh positif dan signifikan terhadap keputusan nasabah untuk menabung di Bank Muamalat Indonesia Kota Jambi. Hal ini terlihat dari hasil uji parsial yang menunjukkan nilai thitung masing-masing koefisien regresi yang lebih besar dibandingkan nilai ttabel. Demikian pula secara simultan, variabel produk, pelayanan, dan promosi secara bersama-sama berpengaruh positif dan signifikan terhadap keputusan nasabah untuk menabung di Bank Muamalat Indonesia Kota Jambi yang ditunjukkan oleh nilai Fhitung $(1806,297)$ $>F_{\text {tabel }}(2,70)$ dan nilai signifikansi $F_{\text {hitung }} 0,000<0,05$.

\section{Bibliografi}

Ahmad Mustag, The Furture of Economics: An Islamic Perspektif, Asy Syaamil Press \& Grafika, jakarta, 2017.

Bank Indonesia, Statistik Perbankan Syariah, Jakarta: Indonesia.

Boyd, H. W., Walker, O. C., \& Larreche, J. C. Manajemen Pemasaran. Jakarta: Erlangga.

Departemen Agama, alquran dan terjemahannya, Jakarta, Bumi Aksara.

Didin Hafidudin dan Hendri Tanjung, Manajemen Pemasaran Syariah dalam Praktik, Jakarta: Gema Insani Inpress, 2003.

Endar Sugiyono, Pengaruh Persepsi Produk, Harga dan Promosi Terhadap Omset Penjualan pada Industri Keramik di Kec. Banjarharjo Kab. Brebes, UNNES, 2004. 
Hermawan Kartajaya dan M. Syakir Sula, Syariah Marketing, (Bandung: Mizan,2006.

Kamir, Bank dan Lembaga Keuangan Lainnya, Jakarta: Raja Grafindo, 2016.

Kasmir, Kewirausahaan, Jakarta: Raja Grafido Persada, 2014.

Kotler, P., \& Armstrong, G, Principles of Marketing, New Jersey: Pearson Education.

Kotler, Philip dan Keller, Kevin Lane, Manajemen Pemasaran, Edisi 13. Alih Bahasa Bob Sabran, Jakarta: Erlangga, 2009.

Kotler, Philip, Manajemen Pemasaran, Jilid 1, Edisi Milenium, Jakarta, Prehallindo, 2015.

Kotler, Philip, Manajemen Pemasarn, Jakarta: . Indeks 2007.

Lamb, C. W., Hair, J. F., \& McDaniel, C. Essentials of Marketing, Boston: Cengage Learning.

Lupiyoadi, Rambat dan Hamdani, A, Manajemen Pemasaran Jasa, Edisi Kedua, Jakarta: Salemba Empat, 2011.

Manajemen Mutu Terpadu Total Quality Management, Jakarta: Rosda Karya.

Marius. P Angipora, Dasar-Dasar Pemasaran, Jakarta: Raja Grafindo Persada, 2015.

Philip Kotler dan Gary Armstrong, Prinsip-Prinsip Pemasaran Edisi 12 Jilid 1, Jakarta : Erlangga, 2006.

Philip Kotler dan Kevin Lane Keller, Manajemen Pemasaran Edisi Ketiga Belas Jilidd 2.

Rhenald kasali, Modul Kewirausahaan. Jakarta: Mizan Publika, 2010.

Sofjan Assauri, Manajemen Pemasaran: Dasar, Konsep, dan strategi, Jakarta: Raja Grafindo Persada, 2008.

Sukirno, Ekonomi Kapitalis, Yogyakarta: Elex Media Yogyakarta, 2015.

Suyadi Prawirosentono, Filosofi Baru Tentang Manajemen Mutu Terpadu, Jakarta: Bumi Aksara.

Swastha Bashu, Azas-Azas Marketing, Edisi Ketiga, Yogyakarta: Liberty Offset, 2003.

Tjiptono, Fandi, Strategi Pemasaran, Yogyakarta: CV. Andi Offset, 2008.

Umar, Husein, Riset Pemasaran dan Perilaku Konsumen, Jakarta: Gramedia Pustaka Utama.

Zamir Iqbal dan Abbas Mirakhor, Pengantar Keuangan Islam: Teori dan Praktek, terj. Oleh A.K. Anwar, Jakarta: Prenada Media Group, 2008. 